\title{
PENGARUH KEPEMIMPINAN MOTIVASI DAN DISIPLIN KERJA TERHADAP KINERJA KARYAWAN PADA CV. ARWANA MAS PALEMBANG.
}

\author{
Ahmad Adi Arifai \\ Fakultas Ekonomi dan Bisnis Universitas Muhammadiyah Palembang \\ Email : adi_merry2008@yahoo.co.id
}

\begin{abstract}
ABSTRAK
Penelitian ini membahas tentang pengaruh kepemimpinan, motivasi dan disiplin kerja terhadap kinerja karyawan pada CV. Arwana Mas Palembang. Dengan masalah adalah adakah pengaruh kepemimpinan, motivasi dan disiplin kerja terhadap kinerja karyawan di CV. Arwana Mas Palembang. Sampel dalam penelitian ini sebanyak 41 orang, dengan menggunakan tenik simple random sampling. Data yang digunakan adalah data primer dan data sekunder. Metodepengumpulan data melalui kuesioner dan dokumentasi. Analisis data yang digunakan adalah analisis kualitatif dan kuantitatif. Teknik analisis menggunakan regresi liniear berganda, uji $\mathrm{F}$ (simultan), uji t (parsial). Hasil pengujian yang telah dilakukan dari penelitian ini menunjukkan bahwa hasil perhitungan regresi linier berganda yang didapat $Y=\mathbf{6 , 6 0 1}+\mathbf{0 , 7 9 7} X_{1}+\mathbf{0 , 2 1 0 X} \mathbf{X}_{\mathbf{2}}+\mathbf{0 , 3 1 9} X_{\mathbf{3}}$ untuk uji $F$ didapat $F_{\text {hitung }}(26,270) \geq F_{\text {tabel }}$ $(2,86)$, artinya ada pengaruh kepemimpinan, motivasi dan disiplin kerja terhadap kinerja karyawan di CV. Arwana Mas Palembang. Untuk uji t variabel kepemimpinan $\left(\mathrm{X}_{1}\right)$ diperoleht $_{\text {hitung }}(6,708) \geq t_{\text {tabel }}(2,022)$, artinya kepemimpinan secara parsial berpengaruh terhadap kinerja karyawan. Uji $t$ variable motivasi $\left(X_{2}\right)$ diperoleh $t_{\text {hitung }}(2,235) \geq t_{\text {tabel }}(2,022)$, artinya motivasi secara parsial berpengaruh terhadap kinerja karyawan.Uji $t$ variable disiplin $\left(\mathrm{X}_{3}\right)$ diperoleh $\mathrm{t}_{\text {hitung }}(2,838) \geq \mathrm{t}_{\text {tabel }}(2,022)$, artinya disiplin secara parsial berpengaruh terhadap kinerja karyawan
\end{abstract}

Kata Kunci: Kepemimpinan, Motivasi, Disiplin Kerja dan Kinerja Karyawan.

\section{I.PENDAHULUAN}

\section{A. Latar Belakang Masalah}

Suatu organisasi atau perusahaan, kepemimpinan merupakan salah satu faktor penting karena pimpinan itulah yang akan menggerakan dan mengarahkan karyawan dalam mencapai tujuan dan sekaligus merupakan tugas yang tidak mudah. Tidak mudah karna harus memahami setiap perilaku bawahan yang berbeda-beda, bahwa sukses atau tidaknya usaha pencapaian tujuan organisasi/perusahaan di tentukan oleh kualitas kepemimpinan.

Menurut Edy Sutrisno (2009:213) kepemimpinan adalah suatu proses kegiatan seseorang untuk menggerakan orang lain dengan memimpin, membimbing, mempengaruhi, orang lain untuk melakukan sesuatu agar dicapai hasil yang diharapkan.

Selain kepemimpinan, motivasi juga berperan penting bagi peningkatan suatu kinerja dalam suatu organisasi atau perusahaan. Motivasi adalah suatu faktor yang mendorong seseorang untuk melakukan ativitas tertentu, oleh karna itu motivasi sering kali diartikan pula sebagai faktor pendorong perilaku seseorang. Untuk memenuhi suatu kebutuhan yang mereka butuhkan untuk mendorong kemampuan seorang karyawan menghasilkan suatu kinerja yang baik 
sesuai dengan apa yang di harapkan oleh suatu organisasi atau perusahaan.

Menurut Malayu SP. Hasibuan (2011:14) Motivasi adalah suatu perangsang keinginan (want) daya penggerak kemauan bekerja seseorang, setiap motif mempunyai tujuan tertentu yang ingin dicapai.

Kepemimpinan dan motivasi, disiplin kerja juga merupakan salah satu faktor yang berpengaruh terhadap kinerja. Menurut Sutrisno (2010:231) disiplin kerja pada karyawan sangat dibutuhkan, karena apa yang menjadi tujuan perusahaan akan sukar dicapai bila tidak ada disiplin kerja. Menurut Soegeng Pridjominto, (2013:212) mengemukakan disiplin adalah suatu kondisi yang tercipta dan terbentuk melalui proses dari serangkaian perilaku yang menunjukkan nilai-nilai ketaatan, kepatuhan, keteraturan, dan ketertiban. Karena sudah menyatu dengan dirinya, maka sikap atau perbuatan yang dilakukan bukan lagi atau sama sekali tidak dirasakan sebagai beban, bahkan sebaliknya akan membebani dirinya bilamana ia tidak berbuat sebagaimana lazimnya. Nilai-nilai kepatuhan telah menjadi bagian dari perilaku dalam kehidupanya. Untuk itu disiplin harus ditumbuh kembangkan agar tumbuh pula ketertiban dan efisiensi. Menurut Budi Setiyawan dan Waridin (2006:132), dan Aritonang (2005:21) disiplin kerja karyawan bagian dari faktor kinerja. Hasil penelitiannya menunjukan bahwa disiplin kerja memiliki pengaruh positif terhadap kinerja karyawan.

Berdasarkan hasil survei di CV. Arwana Mas Palembang terindikasi bahwa tingkat kinerja pada perusahaan diindikasikan memiliki tingkat kinerja yang kurang optimal hal ini dapat dilihat dari pencapaian target penjualan produk sebagai berikut:

\section{Tabel 1.1}

Target dan Penjualan Produk CV. Arwana Mas Palembang

Periode Tahun 2013-2016 (Dalam Rupiah)

\begin{tabular}{|c|c|c|c|c|}
\hline N0 & TAHUN & TARGET & REALISASI & $\%$ \\
\hline 1 & 2013 & 1.500 .000 .000 & 1.425 .000 .000 & $95 \%$ \\
\hline 2 & 2014 & 2.000 .000 .000 & 1.520 .000 .000 & $76 \%$ \\
\hline 3 & 2015 & 2.000 .000 .000 & 1.400 .000 .000 & $70 \%$ \\
\hline 4 & 2016 & 2.160 .000 .000 & 1.435 .000 .000 & $66 \%$ \\
\hline
\end{tabular}

Sumber: CV. Arwana Mas Palembang, 2017

Tabel 1.1 menunjukan rata-rata dari penjualan produk CV. Arwana Mas mengalami penurunan. Disebabkan oleh kualitas kerja karyawan yang rendah, dikarenakan karyawan yang lamban dalam melakukan pekerjaannya sehingga banyaknya keluhan pelanggan atas kualitas pelayanan perusahaan. Seperti adanya keterlambatan dalam pengiriman barang yang telah di pesan oleh pelanggan sehingga barang yang terlambat sampai ke tangan pelanggan dan juga terjadi kesalahan dalam jumlah pengiriman barang yang telah dipesan.Serta sarana atau fasilitas yang disediakan juga kurang baik sehingga menghambat karyawan dalam melakukan pekerjaannya, seperti kondisi mobil yang sediakan untuk mengirimkan barang ke pelanggan kurang baik dan jumlah kendaraan yang sedikit sehingga seringnya terjadi keterlambatan dalam pengiriman barang yang telah di pesan.

Berikut ini data jumlah keluhan pelanggan dari tahun 2014 sampai dengan tahun 2016.

Tabel 1.2

Jumlah Keluhan Pelanggan PeriodeTahun 2014 s/d Tahun 2016

Pada CV. Arwana Mas Palembang

\begin{tabular}{|c|c|c|c|}
\hline Bulan & $\mathbf{2 0 1 4}$ & $\mathbf{2 0 1 5}$ & $\mathbf{2 0 1 6}$ \\
\hline Januari & 10 & 12 & 13 \\
\hline Pebruari & 9 & 10 & 12 \\
\hline Maret & 11 & 7 & 10 \\
\hline April & 8 & 9 & 9 \\
\hline Mei & 9 & 6 & 8 \\
\hline Juni & 7 & 9 & 9 \\
\hline Juli & 9 & 11 & 10 \\
\hline Agustus & 8 & 8 & 10 \\
\hline September & 10 & 10 & 9 \\
\hline Oktober & 9 & 7 & 11 \\
\hline
\end{tabular}




\begin{tabular}{|c|c|c|c|}
\hline Nopember & 7 & 10 & 10 \\
\hline Desember & 9 & 9 & 12 \\
\hline Jumlah & 106 & 108 & 123 \\
\hline
\end{tabular}

Sumber : CV. Arwana Mas Palembang, 2017

Berdasarkan tabel diatas, memperlihatkan bahwa jumlah keluhan yang diterima CV. Arwana Mas Palembang meningkat terus menerus dari tahun 2014 sampai 2016. Pada tahun 2014, terjadi 106 keluhan yang diterima oleh CV. Arwana Mas Palembang. Pada tahun 2015, jumlah keluhan yang diterima meningkat sebesar 108 keluhan. Peningkatan yang cukup signifikan terjadi pada tahun 2016 dimana keluhan yang diterima sepanjang tahun tersebut adalah sebesar 123 keluhan. Hal ini dapat mengindikasikan bahwa kinerja karyawan CV. Arwana Mas Palembang terus menurun yang berakibat pada meningkatnya jumlah keluhan selama 3 tahun terakhir.

Kemudian faktor lain yang dapat mempengaruhi kinerja karyawan di CV. Arwana Mas Palembang adalah kedisiplinan karyawan. Disiplin berusaha mencegah permulaan kerja yang lambat atau terlalu awalnya mengakhiri kerja yang disebabkan karena keterlambatan atau kemalasan. Dari hasil wawancara dengan beberapa karyawan, terindikasi adanya penerapan disiplin kerja yang kurang baik dalam CV. Arwana Mas Palembang. Disiplin pegawai di CV. Arwana Mas Palembang perlu dipupuk dan dipelihara dengan baik, karena apabila pegawai tidak disiplin akan mengakibatkan lambatnya pelaksanaan tugas, selain itu juga akan menimbulkan akibat-akibat yang buruk terhadap perusahaan. Berdasarkan hasil survei awal didapatkan disiplin kerja karyawan menurun berlangsung selama tahun 2014 sampai dengan tahun 2016. Disiplin kerja karyawan menurun ditunjukkan dari adanya peningkatan jumlah absensi karyawan yang meningkat seperti yang ditunjukkan pada tabel berikut :
Tabel 1.3

Data Jumlah Karyawan Mangkir

PeriodeTahun 2014 s/d Tahun 2016

Pada CV. Arwana Mas Palembang

\begin{tabular}{|c|c|c|c|}
\hline \multirow{2}{*}{ Bulan } & \multicolumn{3}{|c|}{ Tahun } \\
\cline { 2 - 4 } & $\begin{array}{c}\mathbf{2 0 1 4} \\
(\mathbf{\%})\end{array}$ & $\begin{array}{c}\mathbf{2 0 1 5} \\
(\mathbf{\%})\end{array}$ & $\begin{array}{c}\mathbf{2 0 1 6} \\
(\mathbf{\%})\end{array}$ \\
\hline Januari & 2 & 3 & 2,8 \\
\hline Pebruari & 1 & 1,2 & 1,5 \\
\hline Maret & 1,7 & 1,5 & 1,6 \\
\hline April & 2 & 2,1 & 2,4 \\
\hline Mei & 1,2 & 1,7 & 2,2 \\
\hline Juni & 1,5 & 2 & 2,6 \\
\hline Juli & 1,75 & 1,5 & 1,8 \\
\hline Agustus & 2 & 2,2 & 2,1 \\
\hline September & 1,8 & 1,75 & 1,7 \\
\hline Oktober & 2,7 & 3 & 2,9 \\
\hline Nopember & 2,1 & 2 & 2,6 \\
\hline Desember & 2,3 & 2,5 & 3 \\
\hline Jumlah & 1,74 & 2,04 & 2,05 \\
\hline
\end{tabular}

2017

Sumber : CV. Arwana Mas Palembang,

Berdasarkan tabel 1.3 diketahui bahwa rata-rata karyawan yang mangkir pada tahun 2014 sebesar 1,74 persen, kemudian meningkat pada tahun 2015 menjadi 2,04 persen. Dari tahun 2014 sampai dengan tahun 2015 peningkatan absensi karyawan mencapai 0,3 persen. Kemudian pada tahun 2016 jumlah karyawan yang absen menjadi 2,05 persen. Adanya peningkatan jumlah karyawan yang absen pada tahun 2014 sampai dengan tahun 2016 menunjukkan kedisiplinan karyawan menurun terus selama tiga tahun terakhir. Selain itu, berdasarkan hasil wawancara kepada karyawan diketahui bahwa selama ini belum adanya peraturan kedisiplinan yang jelas.Menurut salah seorang karyawan selama bekerja di CV. Arwana Mas Palembang, tidak ada tindak pendisiplinan yang jelas terhadap karyawan terutama bagian operasional pengiriman dan gudang yang sering keluar masuk perusahaan tanpa izin disaat jam kerja berlangsungdanadanyakaryawan yang tidakmasukkerjatanpaizin. Dikarnakan kurangnya pemberian suatu sanksi atau 
hukuman bagi karyawan yang tidak mengikuti aturan yang berlaku, kurang nya ketegasan seorang pemimpin juga dapat menyebabkan terjadinya penurunan kedisplinan karyawan sehingga seorang karyawan bisa mengulangi kesalahan yang sama. Hal ini juga dapat dipengaruhi oleh kurangnya keteladanan seorang pemimpin dikarnakan pemimpin mewajibkan atau mengharuskan seorang karyawan menaati peraturan yang berlaku sedangkan pemimpin itu sendiri melanggar peraturan yang berlaku pada perusahaan. Apabila hal ini berlangsung terus menerus akan mengakibatkan menurunnya kualitas hasil kerja antara lain pelayanan terhadap pelanggan menjadi tidak optimal.

Berdasarkan uraian di atas dan melihat pentingnya gaya kepemimpinan yang sesuai dengan harapan karyawan, motivasi kerja, disiplin kerja dalam menentukan keberhasilan kinerja di CV. Arwana Mas Palembang maka peneliti ini tertarik mengambil judul :Pengaruh Kepemimpinan Motivasi Kerja Dan Disiplin Kerja Terhadap Kinerja pada CV Arwana Mas Palembang.

\section{B. Rumusan Masalah}

Berdasarkan latar belakang masalah diatas, maka penulis dapat merumuskan masalah dalam penelitian ini sebagai berikut :

Adakah pengaruh kepemimpinan, motivasi dan disiplin kerja terhadap kinerja karyawan di CV. Arwana Mas Palembang?

\section{Tujuan Penelitian}

Berdasarkan rumusan masalah yang telah dikemukakan di atas, maka tujuan dari penelitian ini adalah : Untuk mengetahui pengaruh kepemimpinan, motivasi dan disiplin terhadap kinerja karayawan di CV. Arwana Mas Palembang.

\section{KAJIAN PUSTAKA}

\section{A. Penelitian Sebelumnya}

Penelitian sebelumnya dilakukan oleh Frana Agus Sugianto (2011) dengan judul Pengaruh Motivasi Kerja dan Kepemimpinan Terhadap Kinerja Karyawan (Studi pada PT. Madubaru Yogyakarta). Hasil penelitian menunjukkan motivasi dan kepemimpinan secara bersama-sama berpengaruh signifikan terhdap kinerja keryawan pada PT. Madubaru.

Durrotun Nafisah (2013), Melakukan penelitian dengan judul Pengaruh Gaya Kepemimpinan Motivasi, dan disiplin kerja terhadap kinerja karyawan PT. Hanamas Mulia Balikpapan, Memberikan kesimpulan mengenai pengaruh Gaya Kepemimpinan Motivasi, dan Disiplin kerja yang mampu mempengaruhi produktivitas kerja Gaya Kepemimpinan trasnformasional, Motivasi semangat kerja, displin kerja yang dapat mendukung berorintasi pada tujuan, secara simulan memiliki pengaruh signifikan terhadap produksi kerja.

Tabel II.1

Perbandingan Penelitian Terdahulu

\begin{tabular}{|l|l|l|l|l|}
\hline NO. & \multirow{2}{*}{ Keterangan } & \multicolumn{3}{|c|}{ Nama } \\
\cline { 3 - 5 } & & Frana Agus Sugianto (2011) & Durrotum Nafisah (2013) & Reggy Wulandari (2017) \\
\hline \multirow{2}{*}{1} & $\begin{array}{l}\text { Judul } \\
\text { Penelitian }\end{array}$ & $\begin{array}{l}\text { Pengaruh Motivasi Kerja dan } \\
\text { Kepemimpinan Terhadap } \\
\text { Kinerja Karyawan (Studi pada } \\
\text { PT. Madubaru Yogyakarta). }\end{array}$ & $\begin{array}{l}\text { Pengaruh Gaya } \\
\text { Kepemimpinan Motivasi, dan } \\
\text { disiplin kerja terhadap } \\
\text { kinerja karyawan PT. } \\
\text { Hanamas Mulia Balikpapan }\end{array}$ & $\begin{array}{l}\text { Pengaruh Kepemimpinan, Motivasi, dan } \\
\text { Disiplin Terhadap Kinerja karyawan di } \\
\text { CV.Arwana Mas Palembang }\end{array}$ \\
\hline \multirow{2}{*}{2} & $\begin{array}{l}\text { Rumusan } \\
\text { Masalah }\end{array}$ & $\begin{array}{l}\text { apakah motivasi dan } \\
\text { kepemimpinan berpengaruh } \\
\text { signifikan terhadap kinerja } \\
\text { karyawan pada PT. Madubaru?. }\end{array}$ & $\begin{array}{l}\text { Adakah pengaruh Gaya } \\
\text { Kepemimpinan Motivasi, dan } \\
\text { disiplin kerja terhadap } \\
\text { kinerja karyawan PT. } \\
\text { Hanamas Mulia Balikpapan ? }\end{array}$ & $\begin{array}{l}\text { Adakah Pengaruh Kepemimpinan, motivasi, } \\
\text { disiplin terhadap kinerja karyawan di } \\
\text { CV.Arwana Mas Palembang secara parsial } \\
\text { dan simultan ? }\end{array}$ \\
\hline
\end{tabular}




\begin{tabular}{|c|c|c|c|c|}
\hline 3 & $\begin{array}{l}\text { Jenis } \\
\text { Penelitian }\end{array}$ & Asosiatif & Asosiatif & Asosiatif \\
\hline 4 & $\begin{array}{l}\text { Data yang } \\
\text { digunakan }\end{array}$ & Data Primer dan sekunder & Data primer dan sekunder & Data Primer dan Data Sekunder \\
\hline 5 & $\begin{array}{l}\text { Teknik } \\
\text { Pengumpulan } \\
\text { Data }\end{array}$ & Kuesioner & Kuesioner & Kuesioner \\
\hline 6 & $\begin{array}{l}\text { Teknik } \\
\text { Analisis }\end{array}$ & $\begin{array}{l}\text { analisis deskriptif dan analisa } \\
\text { regresi liner berganda. }\end{array}$ & Analisis regresi berganda & Analisis Regresi Berganda \\
\hline 7 & $\begin{array}{l}\text { Hasil } \\
\text { Penelitian }\end{array}$ & $\begin{array}{l}\text { Adanya pengaruh } r \text { yang } \\
\text { signifikan pada variabel } \\
\text { motivasi dan kepemimpinan } \\
\text { terhadap kinerja karyawan pada } \\
\text { PT.Madubaru secara bersama - } \\
\text { sama. }\end{array}$ & $\begin{array}{l}\text { Terdapat pengaruh yang } \\
\text { signifikan pada variabel Gaya } \\
\text { Kepemimpinan Motivasi, dan } \\
\text { disiplin kerja terhadap } \\
\text { kinerja karyawan PT. } \\
\text { Hanamas Mulia Balikpapan }\end{array}$ & $\begin{array}{l}\text { Terdapat pengaruh yang signifikan pada } \\
\text { variabel kepemimpinan, motivasi, dan } \\
\text { disiplin terhadap kinerja karyawan di } \\
\text { CV.Arwana Mas Palembang baik secara } \\
\text { parsial maupun simultan. }\end{array}$ \\
\hline
\end{tabular}

Sumber : Frana Agus Sugianto (2011), Durrotum Nafisah (2013), Reggy Wulandari (2017)

\section{B. Landasan Teori}

1. Kinerja

Menurut Soekidjo Notoatmodjo (2009:124) kinerja adalah hasil kerja yang dapat di tampilkan atau penampilan kerja seorang karyawan.

Dalam Suparno Eko Widodo, (2015:131), Menurut Mangkunegara (2007) bahwa istilah kinerja dari kata job performance atau actual performance ( prestasi kerja atau prestasi yang sesungguhnya yang dicapai oleh seseorang) yaitu hasil kerja secara kualitas dan kuantitas yang dicapai oleh seorang pegawai dalam melaksanakan tugasnya sesuai dengan tanggung jawab yang diberikan padanya. Lebih lanjut Mangkunegara (2007) menyatakan bahwa pada umunya kinerja dibedakan menjadi dua, yaitu kinerja individu dan kinerja organisasi.

\section{Kepemimpinan}

Menurut Edy Sutrisno (2009:213) kepemimpinan adalah suatu proses kegiatan seseorang untuk menggerakan orang lain dengan memimpin, membimbing, memengaruhi orang lain, untuk melakukan sesuatu agar dicapai hasil yang diharapkan.

Menurut Malayu (2010:170) menyatakan bahwa kepemimpinan adalah cara seorang pemimpin mempengaruhi prilaku bawahan, agar mau bekerja sama dan secara produktif untuk mencapai tujuan organisasi.

\section{Motivasi}

Menurut M. Kadarisman (2012:278) motivasi adalah penggerak atau pendorong dalam diri seseorang untuk mau berprilaku dan bekerja dengan giat dan baik sesuai dengan tugas dan kewajiban yang telah diberikan kepadanya. Menurut Danang Sunyoto (2015:192) motivasi adalah suatu perangsang keinginan daya penggerak kemauan bekerja seseorang, setiap motif mempunyai tujuan tertentu yang ingin dicapai.

Menurut Suparno Eko Widodo (2015:187) motivasi adalah kekuatan yang ada dalam seseorang, yang mendorong perilakunya untuk melakukan tindakan.

\section{Disiplin}

Menurut Malayu S.P Hasibuan (2013:193) disiplin adalah kesadaran dan kesediaan seseorang menaati semua peraturan perusahaan dan norma-norma sosial yang berlaku.

Menurut Veithzal Rivai (2011:825) disiplin adalah suatu alat yang digunakan para manajer untuk berkomunikasi dengan karyawan agar mereka bersediah untuk mengubah suatu perilaku sebagai suatu upaya untuk meningkatkan kesadaran dan kesediaan seseorang menaati semua peraturan perusahaan dan norma-norma sosial yang berlaku.

\section{Hipotesis}

Adanya pengaruh kepemimpinan, motivasi dan disiplin kerja terhadap 
kinerja karyawan di CV. Arwana Mas Palembang.

\section{METODE PENELITIAN}

\section{A. Jenis Penelitian}

Menurut Sugiono (2010:11) jenis

penelitian berdasarkan eksplanasinya antara lain :

1. Penelitian Deskriptif, adalah penelitian yang dilakukan untuk mengetahui nilai variable mandiri, baik satu variabel atau lebih tanpa membuat perbandingan atau menghubungkan dengan variabel lain.

2. Penelitian Komparatif, adalah jenis penelitian yang bersifat membandingkan keberadaan satu variabel atau lebih pada dua atau lebih sampel yang berbeda

\section{Operasionalisasi Variabel}

Tabel 3.1

Variabel, Definisi Variabel, Indikator Penelitian

\begin{tabular}{|c|c|c|c|}
\hline No & Variabel & Definisi Variabel & Indikator \\
\hline 1 & $\begin{array}{l}\text { Kinerja } \\
\text { Karyawan } \\
\quad(\mathrm{Y})\end{array}$ & $\begin{array}{l}\text { Kinerja adalah sebagai tingkat } \\
\text { pencapaian atau hasil tingkat karyawan } \\
\text { dari sasaran yang harus dicapai/tugas } \\
\text { yang harus dilaksanakan dalam kurun } \\
\text { waktu tertentu pada CV Arwana Mas } \\
\text { Palembang. }\end{array}$ & $\begin{array}{ll}\text { 1. } & \text { Kuantitas } \\
\text { 2. Kualitas } \\
\text { 3. Sarana }\end{array}$ \\
\hline 2 & $\begin{array}{l}\text { Kepemimpinan } \\
\text { Karyawan } \\
\left(X_{1}\right)\end{array}$ & $\begin{array}{l}\text { Kepemimpinan adalah suatu proses } \\
\text { kegiatan seseorang untuk menggerakan } \\
\text { orang lain dengan memimpin, } \\
\text { membimbing, mempengaruhi, orang } \\
\text { lain untuk melakukan sesuatu agar } \\
\text { dicapai hasil yang diharapkan pada CV } \\
\text { Arwana Mas Palembang }\end{array}$ & 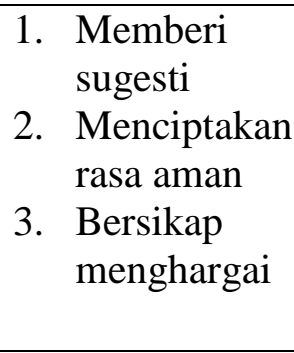 \\
\hline 3 & $\begin{array}{l}\text { Motivasi } \\
\text { Karyawan } \\
\quad\left(\mathrm{X}_{2}\right)\end{array}$ & $\begin{array}{l}\text { Motivasi adalah suatu kekuatan yang } \\
\text { dihasilkan dari keinginan karyawan } \\
\text { untuk memuaskan kebutuhannya pada } \\
\text { CV Arwana Mas. }\end{array}$ & $\begin{array}{l}\text { 1. Lingkunagan } \\
\text { kerja } \\
\text { 2. Penghargaan } \\
\text { 3. Insentif }\end{array}$ \\
\hline 4 & $\begin{array}{l}\text { Disiplin } \\
\text { Karyawan } \\
\quad\left(\mathrm{X}_{3}\right)\end{array}$ & $\begin{array}{l}\text { Disiplin adalah kesadaran dan } \\
\text { kesediaan seseorang menaati semua } \\
\text { peraturan perusahaan dan norma- } \\
\text { norma sosial yang berlaku pada CV } \\
\text { Arwana Mas. }\end{array}$ & $\begin{array}{l}\text { 1. Teladan } \\
\text { pimpinan } \\
\text { 2. Sanksi } \\
\text { hukuman } \\
\text { 3. Ketegasan }\end{array}$ \\
\hline
\end{tabular}

Sumber :Pemikiran penulis berdasarkan teori, 2017 


\section{Populasi dan Sampel}

1. Populasi

Menurut Sugiyono (2013:80)

Populasi (N) adalah wilayah generalisasi yang terdiri atas : obyek/subyek yang mempunyai kualitas dan karateristik tertentu yang ditetapkan oleh peneliti untuk dipelajari dan kemudian ditarik kesimpulannya. Populasi dalam penelitian ini adalah karyawanCV Arwana Mas Palembang, yang berjumlah 45 orang.

2. Sampel

Menurut Sugiyono (2013:81)

Sampel (n) adalah bagian dari jumlah dan karakteristik yang dimiliki oleh populasi tersebut. Dalam penelitian ini penulis menentukan ukuran sampel menggunakan rumus slovin dimana penetepan sampel mempertimbangkan batas ketelitian yang dapat mempengaruhi kesalahan pengambilan sampel populasi. Menurut Anwar Sanusi (2011:101) rumus slovin yaitu:

$$
\begin{aligned}
& \mathrm{n}=\mathrm{N} /\left(1+\mathrm{N}(\mathrm{e})^{2}\right. \\
& \text { Keterangan : } \\
& \text { n : Sampel } \\
& \mathrm{N} \text { : Jumlah } \\
& \text { e : Batas toleransi kesalahan } \\
& \text { (standar eror) }
\end{aligned}
$$$$
\text { Perhitungan Sampel : }
$$$$
\mathrm{n}=45 /\left(1+45(5 \%)^{2}\right)
$$$$
\mathrm{n}=45 /(1+45(0,05))^{2}
$$$$
\mathrm{n}=45 /(1+45(0,0025))
$$$$
\mathrm{n}=45 /(1+0.1125))
$$$$
\mathrm{n}=45 / 0,1125
$$$$
\mathrm{n}=40,4
$$$$
\longrightarrow 41
$$

$$
\text { Responden }
$$

Jadi sampel yang digunakan dalam penelitian ini berjumlah 41 responden. Teknik pengambilan sampel yang digunakan dalam penelitian ini adalah simple randem sampling atau sampel acak sederhana yaitu Menurut Sugiyono (2013:82) dikatakan simple (sederhana) karena pengambilan anggota sampel dari populasi dilakukan secara acak tanpa memperhatikan srata yang ada dalam populasi itu. Teknik ini sampel yang di ambil adalah karyawan di bagian kantor Cv. Arwana Mas Palembang.

\section{E. Data Yang Diperlukan}

Menurut Sugiyono (2013:187). Data diklasifikasikan sebagai berikut:

1. Data Primer, adalah sumber data yang langsung memberikan data kepada pengumpul data.

2. Data Skunder, adalah merupakan sumber yang tidak langsung memberikan data kepada pengumpul data, misalnya lewat orang lain atau lewat dokumen.

Data yang dipergunakan dalam penelitian ini adalah data primer yang berupa hasil kuesioner yang diisi oleh responden, dan sekunder yang berupa jumlah karyawan, sejarah perusahaan dan struktur organisasi pada $\mathrm{CV}$. Arwana Mas Palembang.

\section{F. Metode Pengumpulan Data}

Menurut Sugiyono (2013:137) terdapat beberapa Teknik Pengumpulan Data sebagai berikut :

1. Interview (Wawancara)

Wawancara digunakan sebagai teknik pengumpulan data apabila peneliti ingin melakukan studi pendahuluan untuk menemukan permasalahan yang harus diteliti, dan juga apabila peneliti ingin mengetahui hal-hal dari responden yang lebih mendalam dan jumlah responden yang lebih mendalam dan jumlah respondennya sedikit/kecil.

2. Kuisioner (Angket)

Questioner merupakan teknik pengumpulan data yang dilakukan dengan cara memberi seperangkat pertanyaan atau pernyataan tertulis kepada responden untuk dijawab.

\section{Observasi}

Observasi sebagaiteknik pengumpulan data mempunyai ciri yang spesifikbila dibandingkan dengan teknik yang lain, yaitu wawancara dan kuesioner.

Teknik pengumpulan data dalam penelitian ini adalah kuesioner yang berhubungan dengan indikatorindikator yang digunakan. 


\section{G. Analisis Data dan Teknik Analisis \\ 1. Analisis Data}

Menurut Sugiyono (2013:13-14) analisis data dalam penelitian dapat dikelompokan menjadi dua, yaitu:

a. Analisis Kualitatif adalah suatu metode analisis dengan menggunakan data yang berbetuk kata, kalimat, skema dan gambar atau data non statistik.

b. Analisis Kuantitatif adalah suatu metode analisis dengan menggunakan data berbentuk angka atau kualitatif yang diangkakan.

Analisis dalampenelitian ini adalah analisis kuantitatif dan kualitatif. Analisis kuantitatif dilakukan dengan pengujian statistik dari hasil kuisioner kemudian hasil penguji tersebut akan dijelaskan dengan menggunakan kalimatkalimat. Dengan kata lain, analisis kuantitatif terlebih dahulu digunakan kemudian dilajutkan dengan analisis kualitatif. Analisis Kuantitatif digunakan untuk melihat hasil kuisieoner dengan menggunakan tabulasi (tabelaris) yang berupa penilaian dari hasil pengisian kuisioener.

Menurut Sugiyono (2013:132-136) berbagai skala yang dapat dipergunakan untuk penelitian, yaitu:
a. Skala Likert
b. Skala gutman
c. Rating Scala
d. Semantic deferential

Pada penelitian ini skala yang digunakan adalah skala Likert, maka variabel yang akan diukur dan dijabarkan menjadi indikator variabel. Kemudian indikator tersebut dijadikan titik tolak untuk menyusun item-item instrumen berupa pertanyaan. Jawaban pada skala ini dapat berupa kata-kata antara lain:
Sangat Setuju
(5) $=\mathrm{SS}$
Setuju
(4) $=S$
Ragu-Ragu
(3) $=\mathrm{RR}$
Tidak Setuju
(2) $=\mathrm{TS}$
Sangat Tidak Setuju
(1) $=$ STS

\section{Teknik Analisis}

Teknik Analisis Data

Analisis Regresi Linier Berganda

Metode ini berguna untuk mengetahui seberapa besar pengaruh kepemimpinan, motivasi dan disiplin kerja terhadap Kinerja karyawan Pada CV. Arwana Mas Palembang, digunakan metode analisis Regresi linier berganda. Agar hasil yang diperoleh lebih terarah, maka penulis menggunakan bantuan program software SPSS.

Regresi Linier Berganda

$y=\alpha+b_{1} X_{1}+b_{2} X_{2}+b_{3} X_{3}+e$

Keterangan:

$\mathrm{Y}=$ Kinerja

$\mathrm{X}_{1}=$ Kepemimpinan

$\mathrm{X}_{2}=$ Motivasi

$\mathrm{X}_{3}=$ Disiplin

$\mathrm{a}=$ Nilai Konstanta

$\mathrm{b}_{1} \mathrm{~b}_{2} \mathrm{~b}_{3}=$ Koefisiensi regresi variabel $\mathrm{X}, \mathrm{Y}$

$\mathrm{e}=$ Error Term

\section{HASIL PENELITIAN DAN}

\section{PEMBAHASAN}

A. Hasil Penelitian

Analisis Regresi Liniear Berganda

Analisis Regresi Liniear Berganda ini digunakan untuk mengukur pengaruh antara variabel Kepemimpinan, Motivasi, dan Disiplin kerja terhadap Kinerja Karyawan di CV Arwana Mas Palembang. Hasil analisis tersebut dapat dilihat dari tabel berikut ini :

Tabel IV.1

Analisis Regresi Liniear Berganda

\begin{tabular}{l|r|r|r|}
\hline \multicolumn{4}{|c|}{ Coefficients $^{\mathbf{a}}$} \\
\hline \multirow{2}{*}{ Model } & \multicolumn{2}{|c|}{$\begin{array}{c}\text { Unstandardized } \\
\text { Coefficients }\end{array}$} & $\begin{array}{c}\text { Standardized } \\
\text { Coefficients }\end{array}$ \\
\cline { 2 - 5 } & \multicolumn{1}{|c|}{ B } & Std. Error & \multicolumn{1}{c|}{ Beta } \\
\hline $1 \quad$ (Constant) & 6.601 & 3.070 & \\
Kepemimpinan & .797 & .119 & .717 \\
Motivasi & .210 & .094 & .222 \\
Disiplin & .319 & .112 & .289 \\
\hline
\end{tabular}

Berdasarkan tabel di atas maka bentuk model persamaan regresi untuk pengaruh kepemimpinan, Motivasi, dan Disiplin 
kerja terhadap Kinerja Karyawan di CV Arwana Mas Palembang adalah sebagai berikut :

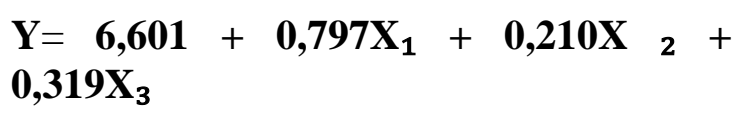

Dari persamaan regresi diatas dapat diinterprestasikan sebagai berikut :

a. Nilai Konstanta adalah 6,601 menyatakan bahwa jika mengabaikan kepemimpinan,motivasi dan disiplin kerja maka skor kinerja karyawan adalah 6,601.

b. Variabel kepemimpinan $\left(\mathrm{X}_{1}\right)$ mempunyai nilai koefisien regresi b1 sebesar 0,797 bernilai positif menyatakan bahwa setiap penambahan satu satuan skor kepemimpinan, akan meningkatkan skor kinerja karyawan 0,797 dengan asumsi 0,797 motivasi kerja $\left(\mathrm{X}_{2}\right)$ tetap/konstan.

c. Variabel motivasi $\left(\mathrm{X}_{2}\right)$ mempunyai nilai koefisien regresi b2 sebesar 0,210 bernilai positif menyatakan bahwa setiap penambahan satu satuan skor motivasi, akan meningkatkan skor kinerja karyawan 0,210 dengan asumsi 0,210displin kerja $\left(\mathrm{X}_{3}\right)$ tetap/konstan.

d. Variabel disiplin $\left(\mathrm{X}_{3}\right)$ mempunyai nilai koefisien regresi b3sebesar 0,319 bernilai positif menyatakan bahwa setiap penambahan satu satuan skor disiplin, akan meningkatkan skor kinerja karyawan 0,319dengan asumsi $0,319 \quad$ kepemimpinan $\left(\mathrm{X}_{1}\right)$ tetap/konstan.

\section{B. PembahasanPenelitian}

\section{Uji F (Simultan)}

Uji F Simultan digunakan untuk mengetahui ada atau tidak adanya pengaruh signifikan kepemimpinan, motivasi, dan disiplin kerja secara bersama - sama terhadap kinerja karyawan di CV Arwana Mas Palembang.maka dilakukan uji F. Berikut hasil dari pengujian statistik Uji F dengan menggunakan Program SPSS versi 17 yaitu :

\section{Tabel IV.2 Hasil Uji F (Simultan)}

\begin{tabular}{|c|c|c|c|c|c|}
\hline \multicolumn{6}{|c|}{ ANOVA $^{b}$} \\
\hline Model & $\begin{array}{l}\text { Sum of } \\
\text { Squares }\end{array}$ & df & \begin{tabular}{|c|} 
Mean \\
Square
\end{tabular} & $\mathrm{F}$ & Sig. \\
\hline 1 Regression & 164.983 & 3 & 54.994 & 26.270 & $.000^{\mathrm{a}}$ \\
\hline Residual & 77.456 & 37 & 2.093 & & \\
\hline Total & 242.439 & 40 & & & \\
\hline
\end{tabular}

Berdasarkan tabel IV.2 Dapat diketahui bahwa nilai $\mathrm{F}$ hitung untuk variabel Kepemimpinan, Motivasi, dan Disiplin terhadap kinerja karyawan adalah 26,270 Sedangkan Ftabel dengan taraf nyata 0,05 dengan $\mathrm{df} 1=\mathrm{k}$ (Jumlah variabel bebas), sedangkan df $2=\mathrm{n}-\mathrm{k}-1=$ 41-3-1 $=37$. Artinya nilai Ftabel df $1=3$ dan df $2=37$ diperoleh nilai Ftabel 2,86.

Jadi dapat diketahui bahwa nilai $\mathrm{F}$ hitung adalah 26,270 lebih besar dari nilai $F_{\text {tabel }}$ yaitu 2,86 . dengan nilai signifikansinya atau lebih kecil dari $\alpha=0,05$. Yang artinya $\mathrm{HO}$ ditolak dan $\mathrm{Ha}$ diterima. Maka disimpulkan bahwa Kepemimpinan, Motivasi, dan Disiplin kerja secara bersama - sama berpengaruh signifikan terhadap kinerja karyawan CV.Arwana Mas Palembang.

Berdasarkan hasil penelitian didapatkan hasil $\mathrm{F}_{\text {hitung }}(26,270)>\mathrm{F}_{\text {tabel }}(2,86)$ sig $\mathrm{F}$ $0,000 \leq \alpha \quad 0,05$. Yang bearti ada pengaruh kepemimpinan, motivasi, dan disiplin kerja terhadap kinerja karyawan secara simultan pada CV. Arwana Mas Palembang. Ini berarti hipotesis penelitian diterima. Cara komunikasi antara pimpinan dengan karyawan jika ditingkatkan lagi, seperti memberikan sikap adil kepada para karyawan dan tidak membedakan antara karyawan seior dan junior. Dalam hal pengambilan keputusan sudah lebih adil dan tegas bisa meningkatkan kinerja karyawan untuk lebih baik lagi. Motivasi untuk mendorong karyawan harus diutamakan, pembayaran uang lembur harus dengan beban kerja karyawan agar peningkatan kinerja 
karyawan bisa menjadi lebih baik. Karyawan yang sudah mendapatkan timbal balik dalam perusahaan memiliki tingkat kinerja yang tinggi dan dapat meningkatkan peningkatan perusahaan. Dan disiplin kerja karyawan yang harus diperhatikan, dengan memiliki ketegasan dalam memberikan hukuman atau sanksi bagi kaywan yang melanggar peraturan, dan memperhatikan karyawan yang sering keluar masuk saat jam kerja. Sehingga faktor-faktor terserbut menunjukkan bahwa variabel-variabel yang terdapat dalam penelitian ini akan mempengaruhi kinerja karyawan, hal ini dapat dilihat dari hasil penelitian uji $\mathrm{F}$.

\section{Uji t (Parsial)}

Uji t (Parsial) bertujuan untuk mengetahui ada atau tidak adanya pengaruh signifikan kepemimpinan, motivasi, dan disiplin secara satu per satu terhadap kinerja karyawan di CV. Arwana Mas Palembang. Berikut hasil dari pengujian statistik Uji $t$ dengan menggunakan program SPSS versi 17 yaitu :

Tabel IV.3

\section{Hasil Uji t (Parsial)}

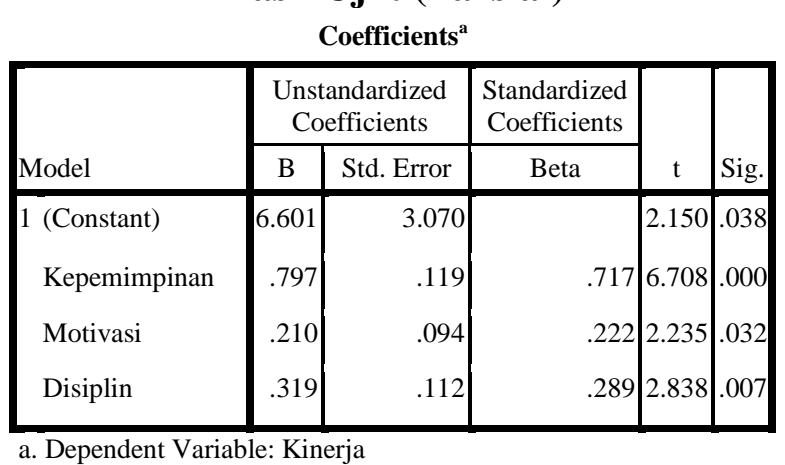

Nilai tabel dengan taraf nyata $(\alpha)=5 \%$ dan df $(n-2)=41-2=39$, adalah sebesar 2,022. Berdasarkan hasil perhitungan diatas dapat dijelaskan bahwa :

a. Hasil uji t untuk pengaruh kepemimpinan terhadap kinerja karyawan di CV. Arwana Mas Palembang menghasilkan nilai $\mathrm{t}$ hitung 6,708 lebih besar dari nilai $t$ tabel 2,022 dengan nilai signifikansinya atau lebih kecil dari alpha 0,05. Dari hasil uji t ini dapat disimpulkan bahwa kepemimpinan berpengaruh signifikan terhadap kinerja karyawan di CV. Arwana Mas Palembang. Dengan demikian berarti secara parsial hipotesis berpengaruh. artinya cara komunikasi dan pengambilan keputusan pimpinan mempengaruhi kinerja karyawan $\mathrm{CV}$. Arwana Mas.

Menurut Edy Sutrisno (2009:213) kepemimpinan adalah suatu proses kegiatan seseorang untuk menggerakan orang lain dengan memimpin, membimbing, memengaruhi orang lain, untuk melakukan sesuatu agar dicapai hasil yang diharapkan.Menurutnya, manajer kurang bekerjasama dengan karyawan, manajer memperlakukan karyawan secara tidak adil antara yang satu dengan yang lain, seperti adanya perbedaan keadilan terhadap karyawan senior dan karyawan junior sehingga menjadikan keirian terhadap karyawan, manajer jarang membimbing dan mengarahkan karyawan yang lambat dalam kerja atau manajer kurang bertanggung jawab. Manajer pun kurang tegas memberikan peringatan atau hukuman kepada karyawan yang bermasalah.

b. Hasil uji t untuk pengaruh motivasi terhadap kinerja karyawan di CV. Arwana Mas Palembang menghasilkan nilai $\mathrm{t}$ hitung 2,235 lebih besar dari nilai $\mathrm{t}$ tabel 2,022 dengan nilai signifikansinya atau lebih kecil dari alpha 0,05. Dari hasil uji t ini dapat disimpulkan bahwa Motivasi berpengaruh signifikan terhadap kinerja karyawan di CV. Arwana Mas Palembang. Dengan demikian berarti secara parsial hipotesisberpengaruh. dan lingkungan kerja di CV. Arwana Mas mempengaruhi kinerja karyawan.

$$
\text { Menurut Danang Sunyoto }
$$

(2015:192) motivasi adalah suatu perangsang keinginan daya penggerak kemauan bekerja seseorang, setiap motif mempunyai tujuan tertentu yang ingin dicapai. Motivasi berpengaruh terhadap kinerja karyawan dalam hal karena 
kurangnya penghargaan atas prestasi berupa pencapaian atas target yang mereka capai, oleh karena itu kurangnya semangat karyawan dalam mencapai target yang diberikan oleh perusahaan. Selain itu lingkungan kerja yang kurang nyaman juga dapat mempengaruhi kinerja seorang karyawan dimana seseorang harus bisa merasa nyaman dalam bekerja sehingga dapat menghasilkan kinerja yang baik. Seperti kurang terciptanya hubungan yang harmonis antar atasan dan karyawan serta antara karyawan dengan karyawan lainnya. Sehingga karyawan merasa kurang nyaman dalam melakukan pekerjaan. Pemberian insentif yang tidak sesuai juga dapat mempengaruhi hasil kerja atau output yang telah dihasilkan oleh karyawan, seperti kurangnya pemberian insentif kepada karyawan yang mendapatkan jam tambahan kerja (lembur).

c. Hasil uji t untuk pengaruh Disiplin terhadap kinerja karyawan di CV. Arwana Mas Palembang menghasilkan nilai $\mathrm{t}_{\text {hitung }} 2,838$ lebih besar dari nilai $\mathrm{t}$ tabel2,022 dengan nilai signifikansinya atau lebih kecil dari alpha 0,05. Dari hasil uji $t$ ini dapat disimpulkan bahwa Disiplin berpengaruh signifikan terhadap kinerja karyawan di CV. Arwana Mas Palembang. Dengan demikian berarti secara parsial hipotesis berpengaruh. dan ketagasan dalam memberi sanksi hukuman CV. Arwana Mas mempengaruhi kinerja karyawan.

Menurut Veithzal Rivai (2011:825) disiplin adalah suatu alat yang digunakan para manajer untuk berkomunikasi dengan karyawan agar mereka bersediah untuk mengubah suatu perilaku sebagai suatu upaya untuk meningkatkan kesadaran dan kesediaan seseorang menaati semua peraturan perusahaan dan norma-norma sosial yang berlaku.Disiplin berpengaruh terhadap kinerja karyawan karena tidak ada tindak pendisiplinan yang jelas terhadap karyawan terutama bagian operasional pengiriman dan gudang yang sering keluar masuk perusahaan tanpa izin disaat jam kerja berlangsung dan adanya karyawan yang tidak masuk kerja tanpa izin. Dikarnakan kurangnya pemberian suatu sanksi atau hukuman bagi karyawan yang tidak mengikuti aturan yang berlaku, kurang nya ketegasan seorang pemimpin juga dapat menyebabkan terjadinya penurunan kedisplinnan karyawan sehingga seorang karyawan bisa mengulangi kesalahan yang sama. Hal ini juga dapat di pengaruhi oleh kurangnya keteladanan seorang pemimpin dikarnakan pemimpin mewajibkan atau mengharuskan seorang karyawan menaati peraturan yang berlaku sedangkan pemimpin itu sendiri melanggar peraturan yang berlaku pada perusahaan.

\section{SIMPULAN DAN SARAN}

\section{A. SIMPULAN}

Hasil analisis dengan regresi liniear berganda yang penelitian dilakukan pada variable kepemimpinan, Motivasi, dan Disiplin kerja terhadap Kinerja Karyawan dengan persamaan $\mathrm{Y}=6,601+0,797 \mathrm{X}_{1}+$ $0,210 X_{2}+0,319 X_{3}$. Hasil pengujian hipotesis menunjukkan :Adanya pengaruh yang signifikan antara Kepemimpinan, Motivasi, dan Disiplin kerja terhadap Kinerja Karyawan Nilai $F_{\text {hitung }}(26,270)>$ $F_{\text {tabel }}(2,86)$, maka Ho ditolak dan $\mathrm{Ha}$ diterima. Ada pengaruh kepemimpinan terhadap kinerja karyawan sebesar 6,708. Hal ini berarti nilai $t_{\text {hitung }}>t_{\text {tabel }}$ yaitu 6,708 $>$ 2,019, maka Ho ditolak dan Ha diterima. Ada pengaruh antara motivasi terhadap kinerja karyawan sebesar 2,235.Hal ini berarti nilai $t_{\text {hitung }}>t_{\text {tabel }}$ yaitu 2,235 > 2,019, maka Ho ditolak dan Ha diterima. Ada pengaruh antara Disiplin terhadap kinerja karyawan sebesar 2,838. Hal ini berarti nilai $t_{\text {hitung }}>t_{\text {tabel }}$ yaitu 2,838> 2,019, maka Ho ditolak dan Ha diterima.

Nilai koefisien dterminasi $R$ Square $\left(R^{2}\right)$ sebesar 0,681 hal ini memberikan makna bahwa variabel kepemimpinan, Motivasi dan Disiplin kerja mampu menjelaskan perubahan terhadap variabel kinerja karyawan sebesar $68,1 \%$. 


\section{B. Saran}

Saran - saran yang dapat disampaikan dalam penelitian ini adalah :

1. Karena kepemimpinan berpengaruh signifikan terhadap kinerja karyawan di CV.Arwana Mas Palembang untuk itu pemimpin sebaiknya selalu memberikan contoh - contoh yang baik kepada bawahannya dan selalu berusaha untuk mengevaluasi pengetahuan dalam bidang pekerjaannya.

2. Karena Motivasi berpengaruh signifikan terhadap kinerja karyawan di CV. Arwana Mas Palembang disarankan bagi perusahaan untuk selalu memberikan umpan balik yang sesuai dengan beban dan tanggung jawab serta memberikan penghargaan pada karyawan yang agar karyawan slelau termotivasi untuk bekerja dengan baik.

3. Karena disiplin berpengaruh signifikan terhadap kinerja karyawan di CV. Arwana Mas Palembang disarankan bagi semua pegawai untuk selalu mentaati semua peraturan yang berlaku di perusahaan serta semua karyawan harus mampu bertanggung jawab dalam setiap tugas yang diberikan.

4. Untuk kinerja karyawan di CV Arwana Mas Palembang bagi semua pegawai untuk saling membantu apabila terjadi masalah dan diharapkan dapat memperoleh hasil yang memuaskan pada setiap pekerjaan yang dilakukan.

\section{Daftar Pustaka}

Danang Sunyoto (2015). Manajemen dan Pengembangan Sumber Daya Manusia. Yogyakarta: CAPS (Center For Academic Publishing Servic)

Durrotun Nafisah (2013). Pengaruh Gaya Kepemimpinan, Motivasi dan Dispilin
Kerja Terhadap Kinerja Karyawan PT. Hanamas Mulia. Balikpapan

EdySurtisno (2009). Manajemen Sumber Daya Manusia. Jakarta :Kencana

Frana Agus Sugianto (2011). Pengaruh Motivasi dan Kepemimpinan Terhadap Kinerja Karyawan PT. Madubaru. Yogyakarta

Handoko (2014). Manajemen. Yogyakarta

M. Kadarisman (2014). Manajemen Pengembangan Sumber Daya Manusia. Jakarta: Rajawali Pers.

Malayu S.P. Hasibuan (2013) Manajemen Sumber Daya Manusia Jakarta: PT. Bumi Aksara

Soekidjo Notoatmodjo (2009). Pengembangan Sumber Daya Manusia. Jakarta: PT Rineka Cipta

Sugiyono (2013) Metode Penelitian Kuantitatif dan Kuualitatif dan $R \& D$ Bandung: ALFABETA, CV

Suparno Eko Widodo (2015). Manajemen Pengembangan Sumber Daya Manusia. Yogyakarta: Pustaka Pelajar Wibowo (2014). Manajemen Kinerja. Jakarta: Rajawali 